\title{
Társas interakciók megfigyeléses vizsgálata integráló óvodai csoportokban
}

\author{
Böddi ZsófiA \\ Eötvös Loránd Tudományegyetem Tanító- és Óvóképző Kar
}

\begin{abstract}
Jelen tanulmány fókuszában az integráló óvodai csoportok társas kapcsolatának vizsgálata áll. Az integráció szociális aspektusa kiemelten fontos annak eredményessége szempontjából. A kutatás célja integráló csoportokba járó sajátos nevelési igényü gyermekek szociális interakcióinak feltárása volt. A természetes megfigyelés módszerét alkalmazva hat sajátos nevelési igényü (nem autisztikus) gyermek (3 lány, 3 fiú, 5 és 7 év közöttiek, átlag életkoruk: 6,17 év) interakcióit vizsgáltam. A megfigyelést öt integráló óvodai csoportban több alkalommal délelőtt készitett videófelvételeken végeztem. A megfigyelési kategóriarendszer kidolgozása és reliabilitásának vizsgálata után összesen közel 5 órányi videofelvétel megfigyelése után az egyes kategóriák frekvenciáinak elemzésével kaptam meg az eredményeket. A megfigyelt sajátos nevelési igényü gyermekek a megfigyelt idöszakokban legnagyobb arányban, az idö több, mint felében játékkal foglalták el magukat. Tevékenységeiket az esetek több, mint felében valakivel interakcióban végezték, interakcióik leggyakrabban egykorú társaikkal folytak. Az eredményeket elemezve és a szakirodalommal összevetve megállapitható, hogy a megfigyelt gyermekek a csoportok tagjaiként, játszótársként vettek részt az óvodai életben, valóban megjelent a szociális integráció.
\end{abstract}

Kulcsszavak: integráció, óvoda, társas interakciók, természetes megfigyelés

\section{Szociális integráció, inklúzió az óvodában}

A sajátos nevelési igényü gyermekek (2011. évi CXC. törvény a nemzeti köznevelésről) integrált, inkluzív óvodai nevelésének kritikus pontja, hogy az elfogadás és befogadás valóban megvalósul-e.

Az inklúzió eredményessége tekintetében kulcstényezőnek tekinthetjük, hogy miként alakul az adott gyermekközösségben a szociális háló, a sajátos nevelési igényű gyermekek milyen társas kapcsolatokkal rendelkeznek. Azaz a fő kérdés, hogy megvalósul-e a társas szempontból az integráció, inklúzió (Bossaert, Colpin, Pijl \& Petry, 2013). „A sikeres beilleszkedés alapja abban a szociális közösségben rejlik, abban a közegben, ahol maga a folyamat

\footnotetext{
1 Jelen tanulmány egyes részei a szerző doktori disszertációjában jelentek meg. Böddi Zsófia (2017): Az óvodai integrált nevelés vizsgálata: Az eredményességet növeló tényezök és az óvóképzés fejlesztésének fókuszával. Doktori disszertáció. Témavezető: Hunyady Györgyné. ELTE PPK, Budapest.
}

zajlik" (Herbainé E Szekeres, 2016. 150. o.). Míg az integráció, inklúzió céljai között szerepel tehát, hogy a sajátos nevelési igényű gyermekek kapcsolatot alakíthassanak ki a tipikusan fejlődő társaikkal (ld. pl. Koster, Nakken, Pijl \& van Houten, 2009; Odom, 2000), gyakran felmerülő kérdéskör, hogy valójában mi jellemzi a gyermekek szociális kapcsolatait (ld. pl. Herbainé \& Szekeres, 2016). Többször ismételt kutatási eredmény az óvodai inklúzió kapcsán a sajátos nevelési igényü gyermekek kevesebb interakcióban való részvétele (Odom, 2000), illetve úgy tűnik, a nagyobb mértékű fejlődésbeli késés kevesebb szociális kapcsolattal jár együtt (Guralnick, 1980, idézi, Odom, 2002). Természetesen a sajátos nevelési igény típusa is hatással van az interakciókra, pl. a nyelvi funkciók sajátosságai nagy jelentőségűek az interakciók alakulása szempontjából (Odom, 2002; Harper E McCluskey, 2002). A sajátos nevelési igényü gyermekek között változatos képet mutat az elfogadottság és a barátságok alakulása (Diamond, Hong \& Tu, 2008). „... a fogyatékos gyermekek szociális integráci- 
Társas interakciók megfigyeléses vizsgálata integráló óvodai csoportokban

ója az inklúzió egyik célja kell, hogy legyen (Guralnick, 1980), ám ez emellett problémát jelent egyes gyermekek számára (Guralnick, 1999)." (Odom, 2002, 167)

Az integrált óvodai környezetben nevelkedő óvodások esetében a fentiek alapján kifejezetten fontos, hogy tudatosan tanulmányozzuk a tevékenységeket, azok társas szintjét (ld. pl. File, 1994; Harper \& McCluskey, 2002; 2003), továbbá tisztában legyünk a felnőttek (pedagógusok) interakciókat befolyásoló szerepével. Azaz a felnőtt támogassa a gyermekek interakcióit akár a játéktámogatásban, akár stratégiák tanításával, vagy konkrét szociális készségeket fejlesztő technikákkal, ugyanakkor ne gátolja az egykorú társakkal folytatott interakciókat (File, 1994; Harper \& McCluskey, 2003; Stanton-Chapman E Snell, 2011; Stanton-Chapman, 2015). Természetesen a fenti megfontolások nem csak a sajátos nevelési igényű gyermekeket fogadó csoportokban, hanem minden óvodai közösségben jelentősek.
Az inklúzió nemzetközi irodalmában az integráció szociális aspektusát fedő fogalmak használata nem teljesen tisztázott. Az alábbi fogalmak jelennek meg: szociális integráció, szociális inklúzió, szociális részvétel (Bossaert et al., 2013; Koster et al., 2009). A nemzetközi irodalom nem teljesen egységes abban a tekintetben, hogy az együttnevelés egyes társas vonatkozásait melyik fenti fogalmakkal írják le. Az alábbiakban Koster és munkatársai (2009) nyomán összefoglalom az integráció társas vonatkozásait. Négy fontos terület emelkedik ki: (1) barátság és kapcsolatok, (2) interakciók és szociális kontaktusok, (3) a sajátos nevelési igényü gyermek vélekedései, ill. (4) a társak általi elfogadás. A kapcsolódó szociális aspektusokat az 1. ábra mutatja be. Az áttekintett társas meghatározók nagy része vonatkoztatható az óvodai integrációra, azonban természetesen néhány összetevő, fóként a sajátos nevelési igényü gyermek önmagáról alkotott vélekedései, ill. a negatív hatások közül pl. a bullying kapcsán inkább az iskoláskorú gyermekekre gondolhatunk.

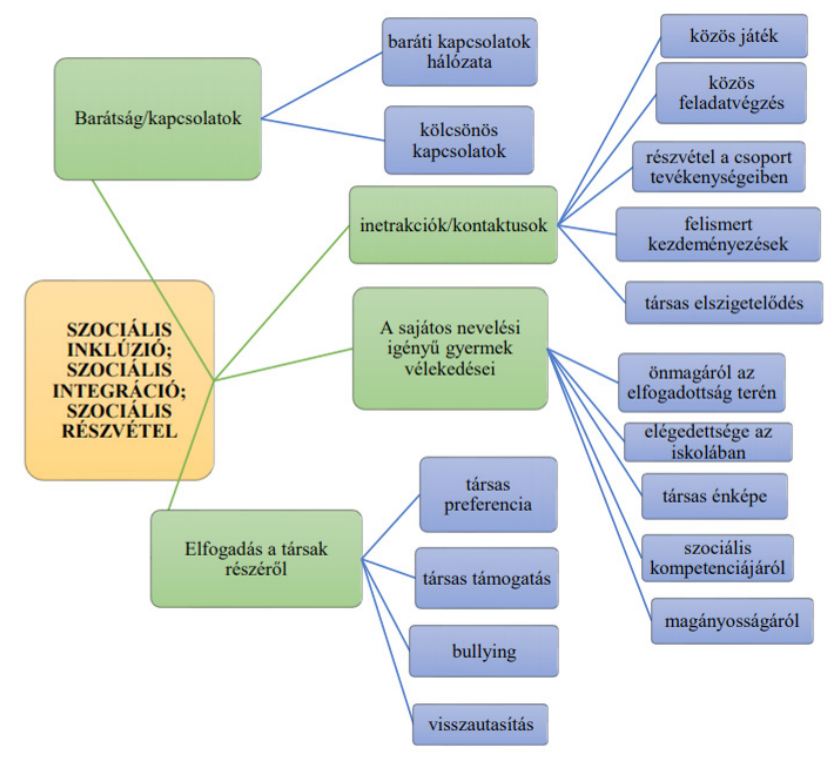

1. ábra: Az inklúzió szociális aspektusához kapcsolódó fogalmak (Koster et al., 2009 nyomán)

Az inklúzió szempontjából meghatározó a befogadás, a tipikusan fejlődő gyerekek viszonyulása a sajátos nevelési igényü társukhoz. A korai életévekben történő együttnevelés esetében különösen nagy jelentőséget kap a fejlődéslélektani nézőpont: „A fogyatékos gyermekek szociális környezetének megértése szempontjából kulcsfontosságú megérteni a tipikusan fejlődő gyermekek gondolkodásá- nak fejlődését fogyatékosságról és a döntéseiket arról, hogy bevonjanak-e egy fogyatékos gyermeket egy tevékenységbe. A fogyatékosság megértése egy meghatározott fejlődésen megy keresztül. Az óvodások esetében azt találták, hogy a látható »jelek« esetében, mint testi és érzékszervi sérülés tudatában voltak a fogyatékosságnak, ám mentális elmaradás vagy érzelmi zavarok esetében nem. Azt tehát 
már az óvodások is megértették, hogy egy látható sérülés következtében valakinek a képességei mások, ám azt, hogy a gondolkodásban vagy az érzelmi reakciók terén is problémája lehet, csak későbbi gyermekkorban, korai serdülőkorban értették meg a gyerekek" (Conant $\mathcal{E}$ Budoff, idézi Diamond, Hong \& Tu, 2008. 142-143. o.).

\section{A társas tevékenységek szintjei óvodai csoportban}

Az óvodai csoportokban megfigyelhető szociális tevékenységi szintek megismerése és leírása kapcsán a két felosztást ismertetek az alábbiakban.

A nemzetközi szakirodalomban alapvetőnek tekinthető Parten (1932, idézi Smith, 2010) felosztása, aki a gyermek társas bevonódásának hat kategóriáját különbözteti meg (1. táblázat). Parten kategóriarendszerét számos kutatásban, később használt megfigyelési kategóriarendszerben megtalálhatjuk (pl. Goldman, 1981; File, 1994; Harper \& McCluskey, 2002, 2003).

\begin{tabular}{|l|l|}
\hline $\begin{array}{c}\text { Tevékenységi } \\
\text { kategória }\end{array}$ & \multicolumn{1}{|c|}{ Leírás } \\
\hline $\begin{array}{l}\text { nem foglalja } \\
\text { el magát } \\
\text { (unoccupied) }\end{array}$ & $\begin{array}{l}\text { a gyermek nem tevékenységgel } \\
\text { foglalja magát }\end{array}$ \\
\hline $\begin{array}{l}\text { szemlél } \\
\text { (onlooker) }\end{array}$ & $\begin{array}{l}\text { a gyermek másokat néz, nem } \\
\text { kapcsolódik be a tevékenységükben }\end{array}$ \\
\hline $\begin{array}{l}\text { magányos } \\
\text { (solitary) }\end{array}$ & $\begin{array}{l}\text { a gyermek egyedül, másoktól } \\
\text { távolabb játszik }\end{array}$ \\
\hline $\begin{array}{l}\text { párhuzamos } \\
\text { (parallel) }\end{array}$ & $\begin{array}{l}\text { a gyermek mások közelében, } \\
\text { azonos/hasonló eszközökkel játszik, } \\
\text { de nem/alig lép interakcióba } \\
\text { velük (pl. egymástól függetlenül } \\
\text { homokoznak) }\end{array}$ \\
\hline $\begin{array}{l}\text { asszociatív } \\
\text { (associative) }\end{array}$ & $\begin{array}{l}\text { a gyermek interakcióban van } \\
\text { másokkal, hasonló dolgokat csinál, } \\
\text { mint a többiek (pl. mindenki } \\
\text { építőkockákat tesz egy épülő } \\
\text { toronyhoz) }\end{array}$ \\
\hline $\begin{array}{l}\text { együttmüködés } \\
\text { cooperative) }\end{array}$ & $\begin{array}{l}\text { a gyermek kiegészítő módon áll } \\
\text { interakcióban másokkal (pl. az egyik } \\
\text { gyermek kockákat hoz, átadja a } \\
\text { másiknak, aki tornyot épít) }\end{array}$ \\
\hline
\end{tabular}

1. táblázat: Parten (1932) felosztása a társas bevonódás kategóriáiról (Smith, 2010)
Hazánkban Mérei Ferenc nevéhez köthető elsősorban az óvodáskorú gyermekek társas tevékenységének kategorizálása. Mérei és munkatársai (Mérei, 1989; Mérei és V. Binét, 2006) az aktometria módszerét használva térképezték fel a társas interakciókat óvodai csoportokban. Ezzel a módszerrel „a csoporttörténéseket helyzetekbe tagoljuk, és személyek szerint felbontjuk a cselekvés társas vonatkozásainak a szempontjából. A cselekvési egységeket jellel látjuk el. Az aktusokra bontott viselkedés formalizált társas elemeit mutatókban összesítjük" (Mérei és $V$. Binét, 2006, 136.). Mérei és munkatársainak (Mérei és V. Binét, 2006) egyik kategóriája a tevékenység társas színvonala, melyből összesen 14-et állapítottak meg (2. táblázat).

\begin{tabular}{|c|c|}
\hline $\begin{array}{l}\text { Aktometria - } \\
\text { tevékenységi } \\
\text { szint }\end{array}$ & Megnevezés \\
\hline I. & $\begin{array}{l}\text { Magányos semmittevés (a gyerek } \\
\text { egyedül van, nem játszik). }\end{array}$ \\
\hline II. & $\begin{array}{l}\text { Magányos semmittevés csoportban (a } \\
\text { gyermek egy csoport társas terében } \\
\text { van). }\end{array}$ \\
\hline III. & Magányos játék. \\
\hline IV. & Mások szemlélése. \\
\hline $\mathrm{V}$. & Öt szemlélik. \\
\hline VI. & $\begin{array}{l}\text { Csoportos semmittevés (együtt } \\
\text { vannak, bámulnak, nézelődnek). }\end{array}$ \\
\hline VII. & $\begin{array}{l}\text { Magányos játék esetleg szemlélődés } \\
\text { csoportban (együtt vannak, de közös } \\
\text { elfoglaltságuk nincs). }\end{array}$ \\
\hline VIII. & $\begin{array}{l}\text { Csoportos szemlélés (közösen } \\
\text { szemlélnek valakit vagy valamit). }\end{array}$ \\
\hline IX. & $\begin{array}{l}\text { A csoport együttesen játszik, a } \\
\text { megfigyelt gyerek külön. }\end{array}$ \\
\hline $\mathrm{X}$. & $\begin{array}{l}\text { Együttmozgás (előfordul, hogy } \\
\text { más-más helyeken, de egyféle } \\
\text { cselekvést végeznek, utánoznak). }\end{array}$ \\
\hline XI. & $\begin{array}{l}\text { Összeverődés egy tárgy körül } \\
\text { (egyazon tárggyal tevékenykednek, } \\
\text { együttműködés nélkül). }\end{array}$ \\
\hline XII. & $\begin{array}{l}\text { Kollaboráció (összedolgozás szerepek } \\
\text { nélkül, pl. építkezésnél). }\end{array}$ \\
\hline XIII. & $\begin{array}{l}\text { Szereposztásos tevékenység (két } \\
\text { formája: a kialakult és a kiosztott } \\
\text { szerepek). }\end{array}$ \\
\hline XIV. & $\begin{array}{l}\text { Szervezett csoporttevékenység } \\
\text { vezetővel és szerepekkel. }\end{array}$ \\
\hline
\end{tabular}

2. táblázat: Az aktometria társas tevékenységi szintjei (Mérei, 1989) 
Társas interakciók megfigyeléses vizsgálata integráló óvodai csoportokban

Egyszerüsítve a számos tevékenységi szintet, a társas tevékenység öt szintjét állapították meg, különböző csoportformáló tényezőkkel: együttlét (hely, tér) - együttmozgás (mozgás, utánzás) - tárgy körüli összeverődés (tárgy) - összedolgozás (tevékenység) - tagolódás (szerep) (Mérei és V. Binét, 2006).

\section{Óvodáskorú gyermekek társas interakcióinak megfigyelése}

Az óvodáskorú gyerekek társas kapcsolatainak tanulmányozása kihívások elé állítja a kutatót. A gyermekek társas kapcsolatainak vizsgálatához megfelelő módszerként kínálkozik a természetes megfigyelés módszere. Koragyermekkorban az írásbeli kikérdezésre nyilvánvalóan nem, de a szóbeli kikérdezés módszereire is csak korlátozottan támaszkodhatunk a szociális kapcsolatok vizsgálatakor (bővebben pl. Pepler E Craig, 1995; Böddi, Keszei, Serfözö és Dúll, 2015; Keszei, Böddi és Dúll, 2016). Felhasználhatjuk más, a gyermekeket jól ismerő személyek, elsősorban felnőttek, pl. a pedagógusok beszámolóit, ám ebben az esetben nem téveszthetjük szem elől, hogy amennyiben a felnőtt beszámolójára építünk, a kapott információ mindenképpen „átment az ő szűrőjén”. Ezt jól illusztrálja McCabe és Marshall (2006) kutatása, melyben specifikus nyelvi zavarral rendelkező óvodások nyelvi kompetenciáját vizsgálták. Módszertanukban mind a megfigyelés, mind a szülők és pedagógusok által kitöltött skálás kérdőív szerepelt a megfigyelt gyermekek szociális készségeinek leírása kapcsán. Vizsgálatukban kis mértékủ és enyhe korrelációt tapasztaltak csak a kétféle módszerrel nyert eredmények között (McCabe és Marshall, 2006).

A megfigyelés mint kutatási módszer számos előnye mellett kalkulálnunk kell annak kihívásaival is (ld. pl. Böddi et al., 2015; Keszei, Böddi és Dúll, 2016). A természetes megfigyelés során nyilvánvalóan felléphetnek torzító tényezők, mint például a résztvevők reaktivitása (azaz a megfigyelt személyek reakciói a megfigyelöre, amely befolyásolhatja a viselkedésüket). A megfigyelt személyek természetes viselkedését esetlegesen befolyásoló hatásokat a kutatónak igyekeznie kell kiküszöbölni, vagy amennyire lehetséges, csökkenteni. A videó (és hang) felvétel készítése például nagymértékben segíthet abban, hogy a megfigyelés minél kevésbé legyen beavatkozó. A nem zavaró helyen elhelyezett kamera vagy kamerák kevéssé vagy alig vannak folyamatosan jelen a gyermekek észlelésében, ill. nem válik nyilvánvalóvá a résztvevők számára, hogy éppen ki a megfigyelt gyermek (Pepler E Craig, 1995).

\section{Kutatási célkitűzések}

A jelen tanulmányban bemutatott vizsgálat egy nagyobb, óvodai integrációt tanulmányozó kutatás (Böddi, 2017) egyik elemét alkotta. Az átfogó kutatás egyik fókusza az volt, hogy a témakör tanulmányozásába beemelje pszichológia aspektust, és tanulmányozzon olyan óvodai csoportokat, ahol régebb óta müködik eredményesen a sajátos nevelési igényü gyermekek integrációja. A jelen írásban bemutatott vizsgálat célja a szociális integráció tanulmányozása, a társas kapcsolatok alakulásának feltárása volt.

\section{Célok:}

A csoportokba járó sajátos nevelési igényü gyermekek társaikkal és a felnőttekkel folytatott interakcióinak feltárása, tevekénységeik társas szintjének meghatározása. A felnőtt interakcióban betöltött szerepének elemzése.

\section{Kutatási kérdések:}

1. Hogyan alakulnak a sajátos nevelési igényü gyermekek interakciói a vizsgált integráló óvodai csoportokban?

2. A tevékenységeiket milyen társas szint jellemzi?

3. Milyen arányban vesznek részt gyermekkel és/vagy felnőttekkel folytatott interakciókban?

4. Milyen arányban kétszemélyesek ezek az interakciók?

5. Milyen mértékben jelenik meg a felnőtt támogatásának szükségessége a sajátos nevelés igényü gyermekkel folytatott interakciókban?

Kutatásom további, módszertani célja volt, hogy egy olyan megbízható viselkedés- 
megfigyelési kategóriarendszer dolgozzak ki, amellyel kódolhatók a gyermekek interakciói.

\section{Módszer}

Kutatásomban szisztematikus megfigyelést végeztem integráló óvodai csoportokban készített videófelvételeken.

\section{Vizsgálati személyek}

Az integráló óvodai csoportban a sajátos nevelési igényü gyermekek interakcióinak vizsgálatához a megfigyelés módszerét választottam. A megfigyeléses vizsgálatokat a kutatásba bevont három budapesti óvoda összesen öt integráló csoportjában végeztem ${ }^{2}$. Ezt megelőzően a tesztfelvételek egy részét egy negyedik budapesti óvoda középső csoportjában vettük fel, ill. itt dolgoztuk ki az adatgyüjtés pontos eljárását ${ }^{3}$.

A kutatásba bevont felvételeken szereplő csoportok közül egy életkor tekintetében homogén középső-, a többi heterogén összetételű csoport volt. Az öt csoportba összesen 9 sajátos nevelési igényű gyermek járt (3 lány és 6 fiú), ill. az egyik csoportba akkoriban érkezett egy fiú, akinek a diagnosztizálása folyamatban volt. Ezen kívül az egyik csoportban volt egy kislány, aki csak néhány órát járt naponta óvodába, vele nem is találkoztam, és egyik felvételen sem szerepelt. A csoportok szerinti megoszlást tekintve egy-egy csoportban volt egyetlen sajátos nevelési igényü gyermek, a többiben kettő vagy három.

Az autizmus spektrum zavar nagymértékben érinti a személy szociális interakcióit (ld. Csepregi és Stefanik, 2012; American Psychiatric Association, 2014), következésképpen egy autista gyermek esetében nyilvánvalóan másként kell értelmezni a gyermek óvodai interakcióit, társas

\footnotetext{
2 A kutatást az Eötvös Loránd Tudományegyetem Etikai Bizottsága engedélyezte (2015). Az óvodákban történő megfigyeléses kutatáshoz, a videófelvételek készítését beleértve, írásbeli hozzájárulást kértem az óvodavezetéstől, illetve a gyermekek kutatásban történő részvételéről a szülőktől írásbeli engedélyt kaptam.

3 A kutatás megfigyeléses részében a videofelvételek készítése közös munka Keszei Barbarával (Eötvös Loránd Tudományegyetem Pszichológiai Doktori Iskola).
}

kapcsolatait, mint akár a tipikusan fejlődő, akár a szociális területet nem, vagy másképp érintő sajátos nevelési igényü gyermekeknél (vö. Bakonyi, 2015), ezért a szociális integráció megfigyelését célzó vizsgálatom mintájából kihagytam az autizmus spektrum zavarral rendelkező gyermekek interakcióinak megfigyelését. Úgy vélem, az ő interakcióiknak a megfigyelése és elemzése egy önálló kutatás témája lenne, amelyhez szükséges lett volna az autizmussal rendelkező vizsgálati személyek számát növelni, és az autizmus sajátosságait figyelembe véve elemezni a megfigyelés társas aspektusait. Továbbá a megfigyelésből kihagytam egy olyan gyermeket, akinek az esetében az óvónők elmondása alapján nem volt számomra egyértelmű a problémája.

Tehát így hat sajátos nevelési igényü gyermek megfigyelését végeztem (3 lány és 3 fiú). Ezek a gyerekek az óvónők elmondása alapján mindannyian sajátos nevelési igényünek minősültek. A szakértői véleményt egy gyermek esetében olvastam én magam, óvónőtől pontos diagnózist és az előírt fejlesztések megnevezését két gyermek esetében kaptam, a többi gyermek bemutatásánál az óvónők jellemzését, a nyilvánvaló sajátosságokat, és a szülők válaszát (amennyiben válaszoltak az ilyen irányú kérdésemre) tudtam alapul venni.

A megfigyeléses kutatásba bevont gyermekek:

- Kislány (6 éves), szájpadhasadékos, az értelmi funkciói is érintettek, és a beszédje is kevéssé érthető

- Kislány (5 éves), beszédértési és -észlelési zavar

- Kisfiú (7 éves), Down-szindróma ${ }^{4}$

- Kisfiú (6 éves), Down-szindróma, nem osztályozott mentális retardáció, enyhe értelmi fogyatékos (utólag kiderült, hogy a megfigyelés idejében halláscsökkenés is jellemezte)

\footnotetext{
4 Természetesen a szindróma megadása nem tekinthető diagnózisnak, hiszen a Down-szindróma esetében tudhatjuk, hogy eltérő képességekkel rendelkezhetnek a gyermekek. Azonban a szindróma diagnózis is informál a gyermekkel kapcsolatos feladatokról (Lányiné, 2014), ill. feltételezhetjük, hogy bizonyos képességek érintettek a Down-szindróma esetében, így a gyermek különleges bánásmódot igényel. Ennek a kisfiúnak a diagnózisáról pontosabb információt sajnos nem tudok.
} 
Társas interakciók megfigyeléses vizsgálata integráló óvodai csoportokban

- Kislány (7 éves), kevert specifikus fejlődési-egyéb pszichés fejlődési zavar (egy korábbi diagnózis felülbírálása után), de hangsúlyos tünete - több más mellett a beszéd területén volt (korábban nemvagy artikulálatlan beszéd jellemezte, a megfigyelés idejében is nagyon nehezen volt érthetö a beszéde)

- Kisfiú (6 éves), egyéb pszichés fejlődési zavar/súlyos tanulási zavar (korai krónikus betegség, ill. a fejlődése több területen megkésett)

\section{Adatgyüjtés}

A megfigyeléses vizsgálatom tervezésében az egyik legfontosabb szempont volt, hogy minél inkább megvalósuljon a természetes megfigyelés, azaz a lehető legkevésbé avatkozzak be a vizsgálati személyek természetes viselkedésébe, reakcióiba. Ezért kutatótársammal ${ }^{5}$ úgy döntöttünk, hogy - csökkentendő a megfigyelők jelenlétéből fakadó hatásokat - nem kézből vesszük fel a történéseket, hanem videokamerákat helyezünk ki a csoportszoba meghatározott pontjaira, hogy így különböző szögekből felvéve az eseményeket, lefedjük a csoportszoba összes játékterét, azaz rögzítünk egy időben minden történést. A kamerák helyének és dőlésszögének meghatározása pontos beállítást igényelt. Ezen kívül, hogy minél kevésbé zavarjuk a csoport életét, a videokamerák kb. 90 perc időtartamban rögzítettek mindent, megszakítás nélkül, és csak a felvétel leteltével mentünk vissza leszedni őket.

A videófelvételek készítésére minden esetben délelőtt került sor, a szabad játék idejében, illetve, ha az időtartamba beleesett, akkor a felnőtt által irányított tevékenység közben. Egy óvodai csoportban általában három alkalommal készítettünk felvételeket. A technikai nehézségek lehetőség szerinti kiküszöbölésen túl, a módszer egyik kulcsfontosságú tényezőjének az instrukciók adása bizonyult. Egyrészt a kamerák kihelyezésekor a kérdezősködő gyerekek kérdéseire fontos volt röviden és informatívan, a felvételkészítés jelentőségét csökkentve re-

\footnotetext{
${ }^{5}$ Köszönettel tartozom Keszei Barbarának az adatgyűjtésben nyújtott pótolhatatlan segítségéért.
}

agálni, másrészt az óvodapedagógusokat úgy instruálni, hogy ne hívják fel a figyelmet a kamerákra (ahogy ez pl. az első, kutatásba végül nem bevont óvodában a tesztfelvételek készítésekor megtörtént), hanem a lehető legtermészetesebben reagáljanak a gyerekek kérdéseire. (Az adatgyüjtés részleteivel kapcsolatban részletesen ld. Keszei, Böddi és Dúll, 2016.)

$\mathrm{Az}$ 3. táblázatban a megfigyelés mint módszer alapkérdései (Szokolszky, 2004) alapján röviden összegzem a jelen kutatásban használt módszer sajátosságait.

\begin{tabular}{|c|c|}
\hline $\begin{array}{c}\text { A } \\
\text { megfigyeléses } \\
\text { kutatási } \\
\text { módszer } \\
\text { kérdése }\end{array}$ & A kutatás jellemzői \\
\hline Mi a célja? & $\begin{array}{l}\text { Integráló óvodai csoportokban } \\
\text { megfigyelhető interakciós mintázatok } \\
\text { leírása; a gyermek-gyermek és felnőtt- } \\
\text { gyermek interakciók megragadásához } \\
\text { szükséges megbízható } \\
\text { kategóriarendszer kidolgozása }\end{array}$ \\
\hline Kit? & $\begin{array}{l}\text { A csoportokba járó óvodás } \\
\text { gyermekek } \\
\text { A csoportok óvodapedagógusa(i) } \\
\text { Összesen } 4 \text { óvoda } 6 \text { csoportja (a } \\
\text { tesztfelvételekkel együtt), ebből } \\
\text { integráló: } 3 \text { óvoda } 5 \text { csoportja }\end{array}$ \\
\hline Mit? & $\begin{array}{l}\text { Integráló óvodai csoportokban } \\
\text { megfigyelhető gyermek-gyermek és } \\
\text { felnőtt-gyermek interakciók }\end{array}$ \\
\hline Hol? & $\begin{array}{l}\text { Természetes megfigyelés, saját óvodai } \\
\text { csoportszobában }\end{array}$ \\
\hline Mikor? & $\begin{array}{l}\text { Óvodai csoportonként } 3 \text { alkalommal } \\
\text { a délelőtti órákban, a szabad } \\
\text { játék ideje alatt, illetve az ez alatt } \\
\text { előforduló felnőtt irányította } \\
\text { tevékenységek közben (kb. } 90 \text { percnyi } \\
\text { időtartamban) }\end{array}$ \\
\hline Hogyan? & $\begin{array}{l}\text { Nyílt, résztvevő megfigyelés } \\
\text { (nagyon kis mértékben résztvevő a } \\
\text { kamerák használata miatt), passzív } \\
\text { megfigyelővel. } \\
\text { Strukturált megfigyelés; } \\
\text { tesztfelvételeken a megfigyelési } \\
\text { kategóriarendszer kidolgozása, a } \\
\text { megbízhatóság tesztelése, majd a } \\
\text { felvételek kódolása, ill. az eredmények } \\
\text { megbízhatóságának ellenőrzése }\end{array}$ \\
\hline
\end{tabular}

3. táblázat: A kutatás áttekintése a megfigyelés alapkérdéseire (Szokolszky, 2004) adott válaszok mentén (Keszei, Böddi és Dúll, 2004 nyomán). 
A videofilmek rögzítése mini DV kamerákkal, mini DV kazettákra történt, majd a felvételek digitalizálása követte (ArcSoft ShowBiz programmal).

\section{Az adatok feldolgozása}

\section{A megfigyelési kategóriarendszer kidolgozása}

Kutatásom módszertani célja volt, hogy létrehozzak egy olyan megfigyelési kategóriarendszert, amellyel megragadhatók a sajátos nevelési igényü gyermekek interakciói, hogy képet kaphassak arról, miképpen alakulnak interakciós szempontból a tevékenységeik.

A kategóriarendszer kidolgozásához a szakirodalomban található témában született, hasonló céllal végzett kutatások (pl. File, 1994; Harper és McCluskey, 2002, 2003) kategóriáit vettem alapul, és alakítottam az általam készített felvételeken megfigyelhető viselkedéselemeknek és a megfigyelhetőség „mélységének” megfelelően.

A tevékenységek szociális szintjének meghatározásához az alapot a Parten (1932, idézi Harper és McCluskey, 2002, 2003) nyomán használt kategóriák szolgáltatták, miszerint a szociális szintek a következőképpen alakulnak: magányos játék, párhuzamos játék, szemlélődő („onlooker”) viselkedés és interakció (részletesen ld. pl. Böddi, Keszei, Serfóző és Dúll, 2015).

Az első kategóriarendszerrel arra törekedtem, hogy minden óvodai (csoportszobai) tevékenységformát és annak minden szociális szintjét lefedjem, sőt az interakció sajátosságait tovább részletezzem, különös tekintettel a felnőttel folytatott kétszemélyes interakciók jellegére.

$\mathrm{Az}$ első kategóriarendszert a 4. táblázat mutatja be.

\begin{tabular}{|c|c|c|c|}
\hline Tevékenység & Társas szintje & & \\
\hline Eszik-iszik & Teljesen magányos tevékenység & & \\
\hline Beszélget & $\begin{array}{l}\text { Magányos tevékenység (társas } \\
\text { jelenléttel) }\end{array}$ & & \\
\hline $\begin{array}{l}\text { Nézeget } \\
\text { (könyvet, } \\
\text { tárgyat) }\end{array}$ & $\begin{array}{l}\text { Párhuzamos (parallel) } \\
\text { tevékenység }\end{array}$ & & \\
\hline Alkot & Szemlélődés & & \\
\hline Játszik & $\begin{array}{l}\text { Interakció, interaktív } \\
\text { tevékenység }\end{array}$ & $\begin{array}{l}\text { kétszemélyes interakció } \\
\text { gyermekkel }\end{array}$ & \\
\hline Lézeng & & $\begin{array}{l}\text { kétszemélyes interakció } \\
\text { felnőttel }\end{array}$ & $\begin{array}{l}\text { Beszélget } \\
\text { Ad valamit } \\
\text { Mutat valamire/valamit } \\
\text { Nem verbális } \\
\text { - Odafordul felé } \\
\text { Bólint } \\
\text { Mosolyog rá } \\
\text { Kinyújtja felé a kezét } \\
\text { Odahajol } \\
\text { Testi kontaktus }\end{array}$ \\
\hline Önkiszolgál & & Interakció gyermekcsoporttal & \\
\hline Rakodik & & $\begin{array}{l}\text { interakció felnőtt-gyermek } \\
\text { csoporttal }\end{array}$ & \\
\hline \multicolumn{2}{|l|}{ Konfliktus } & & \\
\hline Egyéb & & & \\
\hline
\end{tabular}

4. táblázat: A tesztfelvételek kódolásakor használt első kategóriarendszer kategóriái 
Társas interakciók megfigyeléses vizsgálata integráló óvodai csoportokban

A megfigyelendő időtartamot felosztottam 10 másodperces szakaszokra, és a kategóriák lehetőségeit tartalmazó előre elkészített táblázatban jelölni kellett, hogy mely kategóriák jellemzők abban a 10 másodperces idősávban. Ezáltal a kategóriák adott 10 másodperces szakaszban dichotómmá váltak (vagy igen, vagy nem), és csak választani kellett (azt/azokat, amelyekbe a kódoló besorolta a viselkedést). Az utasításban szerepelt, hogy akkor tekintünk tevékenységváltozásnak egy történést, ha az újabb viselkedés legalább 5 másodpercig jellemző.

A tesztkódolók a fenti módon kódolták a tesztfelvételeket, és ezt az eljárást tartottam meg a vizsgálatba bevont felvételek kódolásánál is.

A kódrendszer megbízhatóságát 8 kódoló (7 nő, 1 férfi, átlag életkor: 21,88 év) által kódolt videóanyag alapján teszteltem. A tesztfelvételekben több, különböző megfigyelési személyt (gyermeket) kellett megfigyelniük, összesen 52,67 perc időtartamban, azaz 316 db 10 másodperces szakaszban. A kódolók azzal nem voltak tisztában, hogy melyik óvoda, milyen csoportját nézik, ahogy azzal sem, hogy a megfigyelt gyermek sajátos nevelési igényü-e vagy sem (hiszen ennek látható, fizikai jele nem volt).

A kódolók közötti megbízhatóság számítása kutatásmódszertani kihívást jelentett, mivel 8 független kódoló között kellett reliabilitást számítani dichotóm változók esetében, nem ordinális skálán, hiszen azt kódolták, hogy adott kategória megjelent-e (1) vagy sem (0) az adott időszakaszban, amelyek tehát nominális változóknak kezelendők. A megfigyelők közötti megbízhatóság vizsgálatában gyakran alkalmazott Cohen Kappa, Cronbach Alpha (ld. pl. Hayes és Krippendorff, 2007) vagy Kendall-féle W statisztika (Ketskeméty, Izsó és Könyves Tóth, 2011) ennél a megbízhatósági vizsgálatnál nem volt alkalmazható. Helyette a Krippendorff Alpha (KALPHA) kiszámítását választottam (Hayes és Krippendorff, 2007; De Swert, 2012), De Swert (2012) útmutatása alapján. A KALPHA 0,8 értékét tekintik a jó reliabilitás normájának, az elfogadás minimuma 0,67 (esetenként 0,6 amikor viszont szükséges megindokolni, hogy miért fogadjuk el) (De Swert, 2012). (A KALPHA alkalmazása melletti döntés kutatásmódszertani indoklásáról ld. részletesen: Keszei, Böddi, Geszten, Hámornik és Dúll, 2019).

A számítások elvégzése IBM SPSS Statistic 24 programmal történt.

\section{A kategóriarendszer megbizhatósági vizsgálatának eredménye, a végleges kategóriarendszer}

A 8 megfigyelő közötti KALPHA-számítás eredményeiből azokat a kategóriákat tekintettem megbízhatónak, amelyek 0,67 felettiek. A 0,8 és 0,67 közötti KALPHA értékek elfogadásában fontos érv volt, hogy egyes kategóriák viszonylag ritkán fordultak elő. A 0,67 alatti KALPHA értékkel rendelkező kategóriák esetében logikus kategória-összevonások és egyes kódolók kihagyásának vizsgálata is megtörtént De Swert (2012) útmutatásának megfelelően.

A megbízhatónak tekinthető, végleges kategóriarendszer a következőképpen alakult:

\section{Tevékenység}

\section{Eszik-iszik}

Alkot: rajzol, fest, kézműveskedik, valamilyen tárgyat készít

Játszik: gyakorló (funkcionális) játékot játszik (egyszerű, ismétlődő mozdulatokat végez), konstruáló játékot játszik (tárgyakkal manipulál, hogy létrehozzon valamit, építsen, pl. kockákkal épít, legozik), fantázia játékot (pl. mintha játékot, szerepjátékot), szabályjátékot játszik.

\section{A tevékenység társas szintje (Parten}

(1932, idézi Harper és McCluskey, 2002, 2003 nyomán):

Magányos tevékenység: A gyermek másoktól jóval távolabb egyedül van, egyedül folytat valamilyen tevékenységet, amely eltér a viszonylagos közelségben látható gyermekek tevékenységeitől. Játék esetében egyedül játszik játékokkal, amelyek eltérnek a viszonylagos közelben látható társak játékaitól. Nincs interakcióban mással, sem párhuzamos játékkal (hasonló vagy ugyanolyan tevékenység, játék, mint más gyermeké, de nincsenek interakcióban), sem szemmel láthatóan mások 
játékának figyelésével nem foglalja el magát. Beleértendő a magányos ábrándozás, elgondolkodás, csakúgy, mint más magányos tevékenységek, amelyek során másoktól távol egyedül van. Az egyik tevékenységből másikba váltás nem tekintendő magányos tevékenységnek, pusztán azért, mert azt egyedül teszi a gyermek (pl. átmegy valahova).

Interakció, interaktív tevékenység: A gyermek olyan viselkedése, amely egy felnőtt vagy egy társ felé irányul, és választ, reakciót vált ki, vagy ez a célja. Ilyen reakció például a beszéd, a másik megérintése, egy tárgy odaadása, valami megmutatása neki, figyelmének felkeltése, kooperáció egy közös tevékenységben. Illetve ide tartozik, ha a megfigyelt gyermek reagál, választ ad a másik személy ilyen jellegű kezdeményezésére. Tehát verbális és nem verbális kapcsolat látható a személyek között. Játék esetében hasonló vagy ugyanazon játékokkal játszanak, egy játékban vesznek részt. Ebbe a kategóriába értendő, ha a gyermek a többiekkel párhuzamos tevékenységet végez (pl. asztalnál külön-külön asztali játékkal játszanak, rajzolnak, egyénileg készítenek valamit), de az egyéni tevékenysége mellett periodikusan megjelennek a társas interakció jelei (pl. a tevékenység közbeni beszélgetés, testi kontaktus, közös fókuszú figyelem).

\section{Alkategória: az Interakció jellege:}

- kétszemélyes interakció gyermekkel

- kétszemélyes interakció felnőttel

- testi kontaktus a felnőttel

- csak gyermekekkel van interakcióban van (Gyerek): ebbe a kategóriába tartozik, ha felnött jelenléte nélkül, csak gyermekekkel van interakcióban a megfigyelt gyermek. Ide (is) tartozik az is, ha kétszemélyes interakcióban van egy gyermekkel és az is, ha gyermekcsoporttal van interakcióban (kettő vagy kettőnél több gyermekkel)

- felnőtt van az interakcióban (Felnőtt): ebbe a kategóriába tartozik, ha felnőtt jelenlétében van interakcióban a megfigyelt gyermek. Ide (is) tartozik az is, ha kétszemélyes interakcióban van egy felnőttel és az is, ha felnőtt-gyermekcsoporttal van interakcióban (azaz az interakcióban részt vesz a felnőttön és a megfigyelt gyermeken kívül még egy vagy több gyermek)

A végleges kategóriarendszerbe tartozó kategóriák KALPHA értéke a következőképpen alakult (5. táblázat) a megbízhatósági számításoknál.

Az Interakció kategória alkategóriája esetében szükségesnek bizonyult az egyik kódoló kihagyása a számításokból, és így nőtt az alkategóriák KALPHA értéke. Míg ez a kódoló megbízhatóan kódolta a nagyobb kategóriákat, az alkategóriára bontásban, azaz még specifikusabb észlelésben már nem bizonyult precíznek, így szükségessé vált a kihagyása az alkategória-számításból.

\begin{tabular}{|l|c|}
\hline \multicolumn{1}{|c|}{ Kategória neve } & $\begin{array}{c}\text { KALPHA } \\
\text { értéke }\end{array}$ \\
\hline Eszik-iszik & 0,96 \\
\hline Alkot & 0,89 \\
\hline Játszik & 0,77 \\
\hline Magányos & 0,71 \\
\hline Interakció & 0,72 \\
\hline Kétszemélyes gyerek & 0,70 \\
\hline Kétszemélyes felnőtt & 0,68 \\
\hline Testi kontaktus a felnőttel & 0,74 \\
\hline $\begin{array}{l}\text { Gyerek (Kétszemélyes gyerek + } \\
\text { Gyerekcsoport) }\end{array}$ & 0,71 \\
\hline $\begin{array}{l}\text { Felnőtt (Felnőtt_gyerek csoport + } \\
\text { Kétszemélyes felnőtt) }\end{array}$ & 0,74 \\
\hline
\end{tabular}

5. táblázat: A megfigyelés végleges

kategóriarendszere és a kategóriákhoz tartozó KALPHA értékek a 8 megfigyelővel számított reliabilitás vizsgálat után. Világosszürkével a fó kategóriák vannak kiemelve, az alkategóriák fehérek.

Mivel az eredeti kategóriarendszerből több kategória is kihagyásra került, ezért a végleges, adatelemzéshez szükséges kódolásnál mind a tevékenység, mind a társas szint esetében bevezettem egy egyéb kategóriát, hogy a kódoláskor legyen hova jelölni, amikor a gyermek viselkedése egyik végleges kategóriába sem esik, hiszen pl. lehet, hogy „egyéb” tevékenységet végez, de a társas szintjének kategóriája megadható. Természetesen az „egyéb” kategóriákat a végleges számításokból kihagytam, hiszen azok megbízhatóságának tesztelése nem történt meg. 
Társas interakciók megfigyeléses vizsgálata integráló óvodai csoportokban

Az adatok elemzése a végleges

kategóriarendszer használatával

Az eredmények megbízhatóságának biztosításához egy független megfigyelő a végleges kategóriarendszer betanulása után, velem párhuzamosan kódolta a megfigyelt személyek, azaz a csoportokba járó sajátos nevelési igényü gyermekek viselkedését a felvételeken ${ }^{6}$. A kódolás a fent bemutatott módon történt. A rendelkezésre álló megszakítások nélküli csoportonkénti háromszor kb. 90 percnyi felvételt a kezdetétől indulva 15 perces egységekre bontottam, amelyekből az első öt percet kódoltam. A független megfigyelő és az én kódolásom eredményei között szintén számítottunk reliabilitást. Mivel ebben az esetben, mivel csak két független kódoló között volt szükség a megbízhatóság tesztelésére, a Cohen-kappa számítását választottam. Az egyes kategóriák megbízhatósága a következőképpen alakult (6. táblázat).

\begin{tabular}{|l|l|}
\hline \multicolumn{1}{|c|}{ Kategória neve } & \multicolumn{1}{c|}{$\begin{array}{c}\text { Cohen-kappa } \\
\text { értéke }\end{array}$} \\
\hline Eszik-iszik & 0,92 \\
\hline Alkot & 0,92 \\
\hline Játszik & 0,66 \\
\hline Magányos & 0,5 \\
\hline Interakció & 0,67 \\
\hline Kétszemélyes gyerek & 0,60 \\
\hline Kétszemélyes felnőtt & 0,69 \\
\hline Testi kontaktus a felnőttel & 0,61 \\
\hline $\begin{array}{l}\text { Gyerek (Kétszemélyes gyerek + } \\
\text { Gyerekcsoport) }\end{array}$ & 0,62 \\
\hline $\begin{array}{l}\text { Felnőtt (Felnőtt_gyerek csoport } \\
+ \text { Kétszemélyes felnőtt) }\end{array}$ & 0,74 \\
\hline
\end{tabular}

6. táblázat: A megfigyelés eredményeinek

megbízhatóságát célzó kódolás megbízhatósági vizsgálata a teljes megfigyelt anyagon (két megfigyelő közötti megbízhatóság).

Az eredmények tekintetében mind a tíz kategóriával kapott adatokat megbízhatónak tekintettem. „A megbízhatósági mutató értéke 0 és 1 között mozog. Ha a kódok meg-

${ }^{6}$ Köszöntettel tartozom Szathmári Editnek a független megfigyelőként végzett kódoló munkájáért. egyeznek, akkor a kódolás megbízhatósági mutatója 1. Minél nagyobb az eltérés a kódolások során, vagyis minél kevesebb az egyező kódkategória, a kódolás megbízhatósági mutatója annál kisebb 1-nél. A kvalitatív kutatásmódszertanban jelenleg nincs egyértelmü álláspont a megbízhatósági mutató értékére vonatkozóan. Így pusztán azt követeljük meg, hogy szituációtól függően végezzük el a kódolás valamelyik verzióját és törekedjünk a minél nagyobb érték elérésére." (Sántha, 2012. 69. o.)

Kilenc kategória esetében a Cohen-kappa értéke 0,6 felett van, ami elfogadható (Sántha, 2012), egyetlen kategória, a Magányos esetében az érték 0,5. A kategóriát megtartottam, figyelembe véve, hogy ebben az egyetértésünk a kódolóval kisebb mértékű volt, ugyanakkor az eltérés nem tekinthető nagynak. Feltételezhetően nehézséget okozott a kódolónak elkülöníteni az óvodai csoportokban lehetségesen előálló magányos helyzeteket (pl. társak jelenlétében). A kisebb mértékű egyetértésből kiindulva, egy további kutatásban érdemes lenne árnyalni a Magányos kategóriát, pontosítani az óvodai csoportokban előálló lehetséges magányos tevékenységeket.

\section{Adatelemzés}

A megfigyelt hat gyermek viselkedését a teljes időtartamban végigkódoltam, majd töröltem azokat az időszakaszokat, ahol nem lehetett kódolni a megfigyelt személy viselkedését (pl. mert nem volt a kamera látóterében, vagy nem volt jól látható). Így összesen 1784 db 10 másodperces szakaszban történt megfigyelés, azaz közel öt órányi (4,95 óra) időtartamban kaptam adatot a hat sajátos nevelési igényü gyermek viselkedéséről. Az adatok elemzése Microsoft Excel és IBM SPSS Statistic 24 programokkal történt.

Az adatok elemzése során frekvenciákat számoltam, egyrészt a konkrét megfigyelt kategóriákét, másrészt azokból létrehoztam olyan összekapcsolt kategóriákat, amelyek további információt adhattak a társas interakciókról. 


\section{Eredmények}

A kutatási kérdéseimre a válaszokat a kódolt kategóriák, ill. az összekapcsolt kategóriák frekvenciái alapján adtam meg. Azt elemzem, hogy a megfigyelt gyermekek milyen arányban tevékenykednek magányosan, illetve másokkal - felnőttel és/vagy gyermek(e)kkel interakcióban.

A megfigyelési kategóriák, ill. az azokból képzett összekapcsolt kategóriák frekvenciái a 7. táblázatban láthatók. A kategóriák elfordulási gyakoriságának összege nem egyezik meg az összes megfigyelt időszakasz összegével (1784 db tízmásodperces szakasz), mivel a kódolás során előfordulhatott olyan eset, amikor adott szakaszban több tevékenyéget vagy interakció típust is láttam (a 10 másodperc alatt).

A frekvenciák megadják a választ az első, átfogó kutatási kérdésre: 1. Hogyan alakulnak a sajátos nevelési igényü gyermekek interakciói a vizsgált integráló óvodai csoportokban?

\begin{tabular}{|l|c|c|}
\hline \multicolumn{1}{|c|}{ Viselkedés } & Elöfordulás & $\begin{array}{c}\text { Százalékos } \\
\text { arány }\end{array}$ \\
\hline Eszik-iszik & 101 & $5,66 \%$ \\
\hline Alkot & 257 & $14,41 \%$ \\
\hline Játszik & 1151 & $64,52 \%$ \\
\hline Magányos & 1086 & $30,72 \%$ \\
\hline Interakció & 313 & $62,13 \%$ \\
\hline $\begin{array}{l}\text { Kétszemélyes_ } \\
\text { gyermek }\end{array}$ & 151 & $17,54 \%$ \\
\hline Kétszemélyes_felnőtt & 58 & $8,46 \%$ \\
\hline $\begin{array}{l}\text { Testi kontaktus } \\
\text { (felnőtt) }\end{array}$ & 559 & $31,25 \%$ \\
\hline $\begin{array}{l}\text { Csak gyermekkel van } \\
\text { interakcióban }\end{array}$ & 625 & $35,03 \%$ \\
\hline $\begin{array}{l}\text { Felnőtt van az } \\
\text { interakcióban }\end{array}$ & 143 & $8,02 \%$ \\
\hline Alkot - Magányos & 116 & $6,50 \%$ \\
\hline Alkot -Interakció & 393 & $22,03 \%$ \\
\hline Játszik - Magányos & 720 & $40,36 \%$ \\
\hline Játszik - Interakció & 244 & $13,68 \%$ \\
\hline $\begin{array}{l}\text { Játszik - } \\
\text { Kétszemélyes } \\
\text { gyermek ia. }\end{array}$ & $\begin{array}{l}\text { Játszik - Csak } \\
\text { gyermekekkel }\end{array}$ & $24,55 \%$ \\
\hline
\end{tabular}

\begin{tabular}{|l|c|c|}
\hline $\begin{array}{l}\text { Játszik - } \\
\text { Kétszemélyes felnőtt } \\
\text { ia. }\end{array}$ & 47 & $2,63 \%$ \\
\hline $\begin{array}{l}\text { Játszik - Felnőtt van } \\
\text { az ia-ban }\end{array}$ & 357 & $20,01 \%$ \\
\hline $\begin{array}{l}\text { Összes kódolt } \\
\text { időszakasz }\end{array}$ & 1784 & $100 \%$ \\
\hline
\end{tabular}

7. táblázat: A megfigyelési kategóriák (fehér, szürke és zöld háttér), ill. az azokból képzett társas interakciók szempontjából informatív összekapcsolt kategóriák (kék háttér) előfordulási gyakorisága.

A megfigyelt sajátos nevelési igényü gyermekek tevékenységét tekintve megállapítható, hogy a megfigyelt időszakokban legnagyobb arányban, az idő több, mint felében (1151 eset, 64,52\%) játékkal foglalták el magukat. Kisebb arányban (257 eset, 14,41\%) jelent meg az alkotás (föként rajzolás, mintázás), illetve az étkezés (evés és/vagy ivás) (101 eset, 5,66\%) (2. ábra).

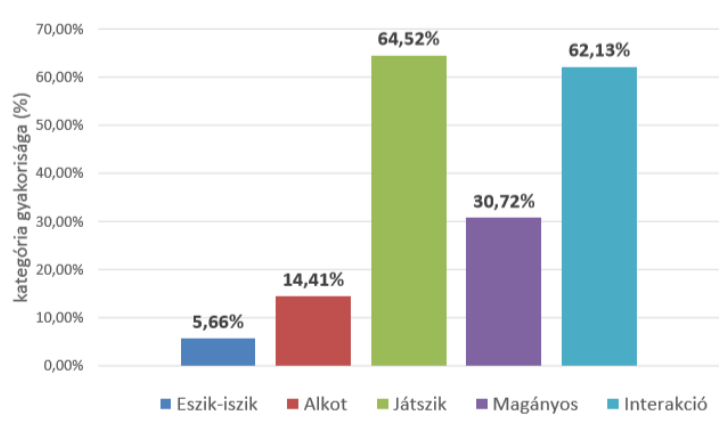

2. ábra: A kategóriák előfordulási gyakorisága az összes kódolt időszakaszhoz viszonyítva (saját ábra)

A következő kutatási kérdésre: 2. A tevékenységeiket milyen társas szint jellemzi? az alábbi frekvenciák adják meg a választ: A társas szint tekintetében tevékenységeiket az esetek több, mint felében (1086 eset, 62,13\%) valakivel interakcióban végezték, a magányos elfoglaltságok ritkábbak voltak (548 eset, 30,72\%-ban) (2. ábra).

A következő frekvenciák adják meg a válaszokat az interakciókat részletező kutatási kérdésekre: 3. Milyen arányban vesznek részt gyermekkel és/vagy felnöttekkel folytatott interakciókban? 4. Milyen arányban kétszemélyesek ezek az interakciók? 5. Milyen mértékben jelenik meg a felnött támogatásának szükségessége a gyermekkel folytatott interakciókban? 
Társas interakciók megfigyeléses vizsgálata integráló óvodai csoportokban

Az interakciókat alkategóriákra is bontottam a kódolásnál, amelyből az látszik, hogy kétszemélyes interakciót összesen 464 esetben láttam, ami az összes időszakasz 26,01\%-a (3. ábra). Ebből 151 esetben (8,46\%) voltak felnőttel (főként óvodapedagógussal, ritkábban dajkával) interakcióban a megfigyelt gyermekek, és több, mint kétszer annyi alkalommal, 313-szor (17,54\%) egy társukkal folytattak interakciót. A felnőttekkel kialakult kétszemélyes helyzetben mindössze 58 esetben $(3,25 \%)$ jelent meg testi kontaktus a résztvevők között.

Végül, az interakciókat tekintve közel hasonló arányban fordul elő, hogy a tevékenysége közben kizárólag gyermekekkel, tehát felnőtt jelenléte nélkül volt kapcsolatban a megfigyelt gyermek (559 eset, 31,33\%), és hogy felnőtt is jelen volt az interakcióban (625 eset, 35,03\%), bár az utóbbi kicsivel nagyobb arányban jellemezte az interakciókat. Az utóbbi kategóriába tartoztak azok a tevékenységek, amelyekben egyszerü résztvevő volt a felnőtt, de a felnőtt által irányított tevékenységek (pl. kezdeményezések, irányított játék) is.

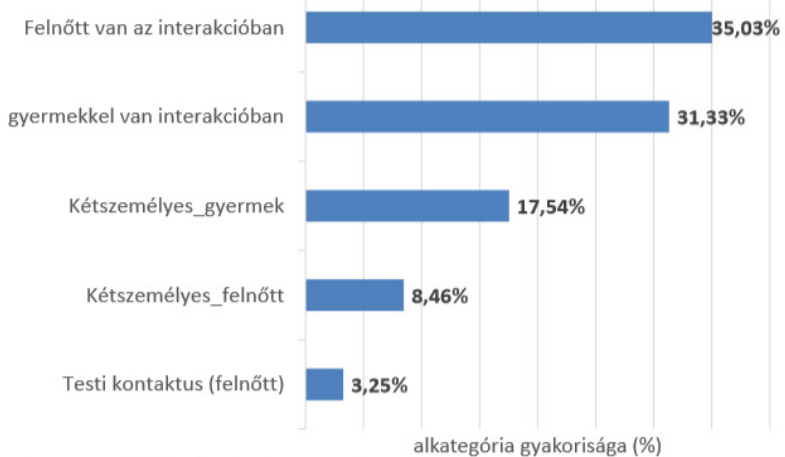

3. ábra: Az Interakció alkategóriáinak előfordulási gyakorisága az összes kódolt időszakaszhoz viszonyítva (saját ábra)

A társas kapcsolatokat, interakciókat árnyalandó megvizsgáltam egyes - a megfigyelt kategóriákból képzett - összekapcsolt kategóriák frekvenciáját is.

Alkotást inkább magányosan készítettek a gyerekek (143 esetben, 8,02\%) minthogy mással interakciót folytattak volna közben (116 eset, 6,50\%).
A leggyakoribb tevekénységet, a játékot részletesen megvizsgáltam a társas interakciók alakulása mentén (4. ábra). A társakkal történő interakcióban folytatott játék (720 eset, 40,36\%) jellemzőbb volt, mint a magányos játék (393 eset, 22,03\%). Ha az interakcióban folytatott játékot tovább bontjuk, azt láthatjuk, hogy leggyakrabban (438 eset, 24,55\%) úgy játszottak, hogy csak gyermekek, tehát az egykorú társak voltak az interakcióban, ebből valamivel több mint a fele alkalom (244 eset, a teljes idő 13,68\%) kétszemélyes interakció volt. A csak gyermekekkel folytatott játéknál némileg kisebb arányban (357 eset, 20,01\%) voltak az olyan játékot tartalmazó interakciók, amelyekben felnőtt is jelen volt. Ezeknek igen kis része (47 eset, 2,63\%) volt kétszemélyes.

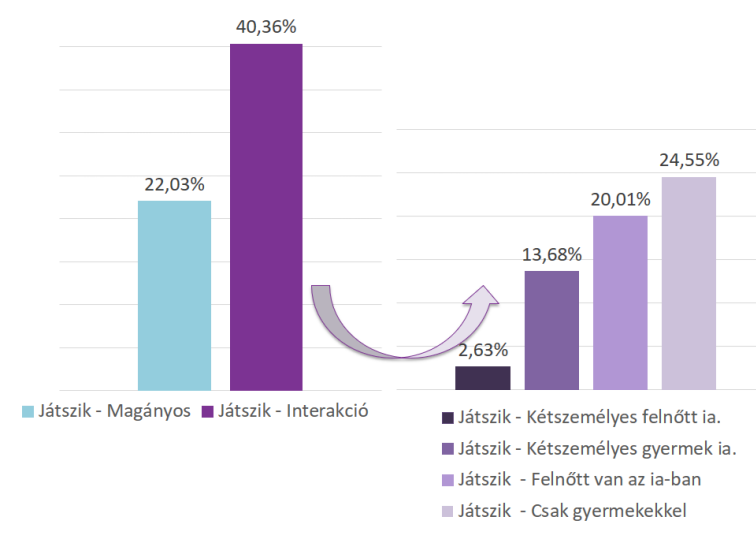

4. ábra: A megfigyelt gyermekek játéktevékenységének alakulása a társas interakciók szempontjából. A kategóriák gyakorisága az összes kódolt időszakaszhoz viszonyítva (saját ábra)

\section{Következtetések}

\section{Az eredmények megvitatása}

A megfigyelt sajátos nevelési igényü gyermekek tevékenységeinek típusait tekintve azt láthatjuk, hogy a megfigyelt idö kisebb részét a kategóriák közül étkezéssel, ill. alkotással, a legnagyobb részét játékkal töltötték. A játék dominanciája természetesen egyrészt a kiválasztott napszaknak is köszönhető, hiszen a megfigyelés mindig a délelőtti órákban, a szabad játék és az esetlegesen beleeső felnőtt által irányított tevékenység közben történt. Továbbá a játék megjelenésének nagy aránya 
összhangban áll az óvodai nevelés egyik legfontosabb alapelvével, miszerint: „A játék a kisgyermekkor legfontosabb és legfejlesztőbb tevékenysége, s így az óvodai nevelés leghatékonyabb eszköze. A játék - szabad-képzettársításokat követő szabad játékfolyamat - a kisgyermek elemi pszichikus szükséglete, melynek mindennap visszatérő módon, hoszszantartóan és lehetőleg zavartalanul ki kell elégülnie" (Óvodai Nevelés Országos Alapprogramja, 2012). Ezen kívül - a fentiekkel összhangban - megfigyelhető volt, hogy több, felnőtt által irányított tevékenység is játékba ágyazottan történt, a gyermekek játékként élték meg azokat (pl. mozgásfejlesztés, egészségnevelés), így játékként volt kódolható.

A tevékenységek több, mint felét a megfigyelt sajátos nevelési igényü gyermekek valakivel interakcióban végezték, és kb. 30\%-át magányosan. Az interakciókban kb. egyenlő arányban jelentek meg a kizárólag gyermekrésztvevős, ill. az olyan interakciók, amelyben felnőtt is részt vett. Az utóbbiakba beleértettem azokat az interakciókat is, amiket a felnőtt instruált (pl. irányított játék). Ha pedig tovább részletezzük a felnőttet is tartalmazó interakciókat, látható, hogy nem a kétszemélyes, azaz egykorú társakat kizáró interakciók dominálnak (hiszen azok csak közel 8,5\%-ban jelentek meg), hanem olyanok, amelyekben jelen van más gyermek is. A fenti arányok alapján általánosságban megállapítható, hogy összességében véve a megfigyelt sajátos nevelési igényü gyerekek nem magányosak a csoportban, nincsenek a közösség perifériáján, hiszen akkor azt tapasztaltam volna, hogy legnagyobb arányban magányosak vagy felnöttel vannak interakcióban és elenyésző arányban gyerekekkel.

Ahhoz, hogy árnyaltabb képet kapjak a szociális integráció megvalósulásáról, részletesen vizsgáltam az óvodáskor fő tevekénységének, a játéknak szociális szempontból történő megvalósulását. E tekintetben azt tapasztaltam, a megfigyelt gyermekek kb. 22\%ban játszottak magányosan, míg kb. 40\%-ban másokkal interakcióban, utóbbiból kb. 25\%ban csak gyermekekkel (4. ábra).

A fent említett arányban megjelenő magányos játék nem tekintendő túlzottan nagy arányú, akár az izoláció felé mutató magányos elfoglaltságnak. A szakirodalomban találunk olyan forrásokat (Lyon \& Canning, 1995, idézi Lloyd \& Howe, 2003; Rubin et al., 1976, idézi Lloyd \& Howe, 2003; Rubin et al., 1978, idézi Lloyd E Howe, 2003), melyek szerint óvodáskorban (preschool) a magányos játék gyakorisága kb. 17 és 23\% között mozog, a kifejezetten iskola előtti időszakban (kindergarten) pedig $17 \%$.

Mérei Ferencék (1989) gyermekkori társas kapcsolatok vizsgálatát célzó aktometria módszerével (a kategóriákat ld. 2. táblázatban) végzett kutatásukban az általuk bemutatott óvodás és alsó tagozatos napköziotthonos csoportok esetében az inkább magányos tevékenységekhez köthető tevékenységeket (aktometria VI-IX. csoportosulási forma az együttlét szintjén) 25\%, ill. 10\%-ban találták jellemzőnek (Mérei, 1989). Az általam tapasztalt arányok tehát a szakirodalomban található arányoknak megfelelők. Továbbá Lloyd és Howe (2003) tanulmányában felhívja a figyelmet arra, hogy a magányos játékot nem szükséges feltétlenül negatívumnak tekinteni. Természetesen elismerve a szociális játék pozitívumait, a magányos játék nem feltétlenül „alacsonyabb rendü” a játékfejlődésben, számos előnnyel jár, pl. a játszó gyermek kognitív képességei fejlődnek közben. Továbbá fontos azt is figyelembe venni, hogy a „nem szociális" játéknak különböző formái léteznek: magányos passzív, magányos aktív (pl. ez lehet akár szerepjáték is) és a tartózkodó viselkedés (mások szemlélése vagy elfoglaltság nélküli tevékenység) (Lloyd és Howe, 2003). Fontos megjegyezni, hogy saját kódolásomban a szemlélődést, mások nézését nem kódoltam magányos viselkedésnek. Kutatásom továbblépéseként érdemes lenne részletesebben elemezni, hogy a sajátos nevelési igényü gyermekek a magányos játékuk közben pontosan mivel és hogyan foglalják el magukat.

A szociális integráció és preferencia egyik legfontosabb mutatója a csak gyermekekkel folytatott játék, illetve ezek között a kétszemélyes gyermek-gyermek játékhelyzetek. Az eredményekből látható (4. ábra), hogy a sajátos nevelési igényü gyermekeknek volt ilyen jelle- 
Társas interakciók megfigyeléses vizsgálata integráló óvodai csoportokban

gű interakcióban részük, gyermekekkel az öszszes kódolt eset kb. 25\%-ában játszottak, ebből kétszemélyes játék közel 14\%-ban volt jellemző. Tehát választották őket játszótársnak, illetve nem utasitották vissza az ö közeledésüket sem a társaik. Mérei Ferencék (1989) korábban említett aktometriát használó vizsgálatában a csoportosulás együttléten kívüli, több interakciót tartalmazó formái esetében a passzív formáknál, ami az együttmozgás (aktometria X. csoportosulási forma) és a tárgy körüli összeverődés (aktometria XI. forma), 28-29\%, ill. 2425\%-os előfordulási arányt tapasztaltak. Míg a magasabb szintű aktív csoportosulási formáknál, ami az összedolgozás (aktometria XII. forma) és a tagolódás (aktometria XIII-XIV. forma) $12-13 \%$, ill. 10-23\%-ban volt jellemzö (Mérei,1989). Ez alapján a megfigyelésem során tapasztalt gyermek-gyermek interakció kb. 24\%-os aránya összhangban van az említett kutatásban tapasztaltakkal. A szociális kapcsolatok pontosabb bemutatásához érdemes lenne tovább elemezni a gyermekek egymás közötti interakcióit, vagy más módszerrel is vizsgálni a társas kapcsolatokat, árnyalni az összefüggéseket a sajátos nevelési igény jellege szempontjából, ám jelen vizsgálat alapján is levonható az az összegző következtetés, hogy a megfigyelt sajátos nevelési igényü gyermekek az óvodás közösség részeként müködtek. Interakcióik arányai megfeleltethetők más olyan fent említett forrásoknak, amelyekben óvodás gyermekek interakcióit elemezték.

További fontos aspektus volt a felnőtt interakcióban történő részvétele. A megfigyeléseimben viszonylag magasnak tekinthető azon interakciók aránya, amelyekben jelen volt a felnőtt (kb. 35\%), hiszen kevéssel még többnek is mondható, mint a csak gyermekkel folytatott interakciók (kb. 31\%), ám ha kizárólag a játékot vizsgáljuk, ez az arány megfordul. A megfigyelt gyermekek játék során több időt töltöttek úgy, hogy kizárólag a társaikkal játszottak (kb. 24\%), mint amikor a felnőttnek is volt szerepe a játékukban (kb. 20\%). Ennél az eredménynél fontos figyelembe venni, hogy a megfigyelt időszakokba beleestek irányított játékok is, ahol nyilvánvaló a felnőtt szerepe. Továbbá ebből elenyésző arányban (3\%-nál kevesebb) volt olyan alkalom, amikor a felnőttel kétszemélyes helyzetben játszottak a megfigyelt gyermekek. Tehát valójában elsősorban a társaikkal, esetleg egyedül játszottak.

Kevéssé lehet meghatározni a felnőtt gyermekkel folytatott interakcióinak megfelelő arányát, vagyis, hogy azt mikor tekinthetjük „elégnek”. Óvodáskorban az egykorú társak fontossága mellett kiemelt szerepe van a felnőtteknek a társas kapcsolatokban. „A kisgyermek első valódi játszótársa a családban, az óvodában is a felnőtt - a szülő és az óvodapedagógus. Az óvodapedagógus utánozható mintát ad a játéktevékenységre, majd amikor a szabad játékfolyamat már kialakult, bevonható társ marad, illetve segítővé, kezdeményezővé lesz, ha a játékfolyamat elakad. Az óvodapedagógus jelenléte teszi lehetővé a gyermekek közötti játékkapcsolatok kialakulását is." (Óvodai Nevelés Országos Alapprogramja, 2012). Trawick-Smith \& Dziurgot (2011) Vigotszkij legközelebbi fejlődési zóna megközelítését alkalmazzák a játéktámogatásra, amelyhez empirikus vizsgálatot is kapcsoltak. A modell szerint „a felnőttek az egyéni gyermekek aktuális szükségleteinek megfelelő játéktámogatást nyújtják, amely ezt követően az önálló játék felé vezet." (Trawick-Smith \& Dziurgot, 2011, 110). A szerzők a temperamentumelméletből (pl. Cole E Cole, 2003) ismert „illeszkedés jósága" (goodness of fit) fogalmat is alkalmazzák az óvodapedagógus-gyermek interakcióra, azaz, hogy a fejlődési „kimenetelt” a pedagógus adott gyermekre adott reakciói határozzák meg (Trawick-Smith \& Dziurgot, 2011), ugyanúgy ahogy a temperamentumelméletben az adott gyermek temperamentuma és a gondozói viselkedés illeszkedése tünik döntő tényezőnek (ld. pl. Cole \& Cole, 2003). Tehát, ha a fentieknek megfelelöen müködnek a pedagógusok, akkor mindig az adott gyermek - legyen sajátos nevelési igényű vagy sem aktuális szükségleteihez igazodva lépnek a játékba, támogatják azt.

A felnőtt, azaz legtöbb esetben a pedagógus interakcióban betöltött szerepe kulcsfontosságú a kapcsolatok alakulása szempontjából. Harper E McCluskey (2003) felhívja a figyelmet a pedagógus interakciói terén szükséges 
tudatosságra, hogy az inkluzív csoportban a felnőtt jelenlétével és interakcióba lépésével ne gátolja a sajátos nevelési igényü gyermekek egykorú társakkal folytatott interakcióit (részletesen ld. Harper \& McCluskey, 2003).

A játék támogatása egy különösen „érzékeny" pontja a felnőtt-gyermek interakciónak az óvodában (pl. Slunjski \& Ljubetić, 2014). A játék támogatásában a pedagógusnak nemcsak a játék feltételeit kell megteremtenie, hanem tudnia kell megfelelő módon belépni a játékba és kilépni abból, illetve verbális „módszerek” alkalmazásával támogatni a játékot. Ezeken túl pedig pontosan meg kell tudnia választani a megfelelő játékba avatkozási stratégiákat (Stanton-Chapman, 2015). A kutatás továbblépésében érdemes lenne a pedagógusok játéktámogató viselkedését megfigyelni és elemezni mind a sajátos nevelési igényü, mind a tipikusan fejlődő gyermekek esetében.

Kutatásmódszertani szempontból úgy vélem, teljesült a kutatás kitűzött módszertani célja, miszerint sikerült egy óvodás gyermekek interakcióit megragadó megbízható kategóriarendszert kidolgozni, amelyet későbbi vizsgálatokban érdemes felhasználni, továbbfejleszteni.

\section{Összegzés}

Összegezve a kutatásból nyert eredményeket, az alábbi megállapításokat tehetjük. A sajátos nevelési igényü gyermekek általánosságban véve mind a csoporttársaikkal, mind a felnöttekkel kiegyensúlyozott arányban folytattak interakciókat, némileg gyakoribbnak bizonyultak azok az esetek, amikor felnőtt is jelen volt az interakcióban. Azonban fontos figyelembe venni, hogy a megfigyelések időszakába beleesett a felnőtt által irányított tevékenységek idejéből is. A megfigyelt gyermekek elsősorban játszottak a megfigyelt időszakokban, és ha csak ezt a tevékenységet vizsgáljuk, látható, hogy gyakoribb volt az olyan játék, amelyet kizárólag gyermekekkel folytattak, mint az olyan, amelyben a felnött is szerepelt. A magányos játék közel hasonló arányban jellemezte a gyerekeket, mint a társakkal folytatott játék, azonban aránya nem volt túlzottan magas, nem vezetett olyan megállapításhoz, hogy ezek a gyerekek elszigetelödtek volna a csoportban. Tehát a megfigyelt sajátos nevelési igényü gyermekek a csoport részeként, játszótársként vettek részt a közösségben, és nem kizárólag magányosan vagy felnött irányitással voltak képesek játszani. A kétszemélyes interakciók mind a gyermek-gyermek, mind a gyermek-felnőtt interakció tekintetében ritkábbnak mondhatók szemben a csoportos tevékenységekkel. Különösen a felnőttekkel folytatott kétszemélyes játék bizonyult ritkának. A fenti eredmény, illetve a gyermekekkel folytatott játék magas aránya alapján azt a következtetést vontam le, hogy ezeknek a sajátos nevelési igényü gyermekeknek nem volt szüksége a felnött folyamatos - kétszemélyes - irányitására a játék terén (természetesen nem feledve azt a tényt, hogy az átlagos óvodai csoportlétszámok mellett az óvodapedagógusnak eleve kevés lehetősége adódik kétszemélyes helyzetben játszani egyegy gyermekkel).

$\mathrm{Az}$ ennél részletesebb képhez érdemes lenne a továbbiakban más megfigyeléseket is végezni az interakciók jellegéről, a sajátos nevelési igény jellegével való összefüggéséről, a közös, ill. a magányos játék színvonaláról, tartalmáról, illetve fontos tényező lehet annak megfigyelése, hogy pontosan ki indítja az interakciókat, illetve hogyan alakulnak az esetleges konfliktusok. További hozzáadott érték lehet, ha a felnőtt játéktámogató viselkedését is részletesen megfigyelnénk és elemeznénk.

Összességében úgy vélem, hogy a kutatásomban résztvevő óvodai csoportokban a megfigyelt sajátos nevelési igényü gyerekek valóban a közösség részének tekinthetők, óvodáskorban megfelelőnek mondható interakcióik vannak a társaikkal.

\section{Ajánlás}

Tanulmányomat doktori témavezetőm, Hunyady Györgyné Zsuzsa professor emerita emlékének ajánlom, akinek támogatása nélkül kutatásom nem jöhetett volna létre. Emlékét szívemben örökké őrzöm. 
Társas interakciók megfigyeléses vizsgálata integráló óvodai csoportokban

\section{Felhasznált irodalom}

2011. évi CXC. törvény a nemzeti köznevelésröl URL: http://njt.hu/cgi_bin/njt_doc. cgi?docid=139880.329881 (letöltve: 2020.01.10.)

363/2012. (XII. 17.) Korm. rendelet az Óvodai nevelés országos alapprogramjáról

URL: https://net.jogtar.hu/jogszabaly? docid=a1200363.kor (letöltve: 2020.01.10.)

American Psychiatric Association (2014): DSM-5 referencia-kézikönyv a DSM-5 diagnosztikai kritériumaihoz. Oriold és társai.

Bakonyi Anna (2015): Autizmussal élő gyerekek óvodai integrációja az általános óvodai integráció kontextusában. Fejlesztő Pedagógia, 26. 4-6. sz., 46-53.

Bossaert, G., Colpin, H., Pijl, S. J. \& Petry, K. (2013): Truly included? A literature study focusing on the social dimension of inclusion in education. International Journal of Inclusive Education, 17. 1. sz., 60-79.

https://doi.org/10.1080/13603116.2011.580464

Böddi Zsófia, Keszei Barbara, Serfőző Mónika és Dúll Andrea (2015): A megfigyelés kutatásmódszertana - Interakciók megfigyelése integrált és inkluzív óvodai környezetben. Gyermeknevelés, 3. 2. sz., 29-50.

Böddi Zsófia (2017): Az óvodai integrált nevelés vizsgálata: $A z$ eredményességet növeló tényezők és az óvóképzés fejlesztésének fókuszával. Doktori disszertáció. Témavezető: Hunyady Györgyné. ELTE PPK, Budapest.

Cole, M. és Cole, S. R. (2003): Fejlődéslélektan. Osiris Kiadó, Budapest.

Csepregi András és Stefanik Krisztina (2012): Autizmus spektrum zavarral élö gyermekek, tanulók komplex vizsgálatának diagnosztikus protokollja. Educatio Társadalmi Szolgáltató Nonprofit Kft., Budapest.

De Swert, K. (2012): Calculating inter-coder reliability in media content analysis using Krippendorff's Alpha. University of Amsterdam, Amsterdam.

URL: http://www.polcomm.org/wp-content/ uploads/ICR01022012.pdf (letöltve: 2016.06.01.)

Diamond, K. E., Hong, S. Y. \& Tu, H. (2008): Context influences preschool children's decisions to include a peer with a physical disability in play. Exceptionality, 16. 3. sz., 141-155.

https://doi.org/10.1080/09362830802198328
File, N. (1994): Children's play, teacher-child interactions, and teacher beliefs in integrated early childhood programs. Early Childhood Research Quarterly, 9. 2. sz., 223-240. https://doi.org/10.1016/0885-2006(94)90007-8

Goldman, J. A. (1981): Social participation of preschool children in same-versus mixed-age groups. Child Development, 644-650. https://doi.org/10.2307/1129185

Harper, L. V. \& McCluskey, K. S. (2002): Caregiver and peer responses to children with language and motor disabilities in inclusive preschool programs. Early Childhood Research Quarterly, 17. 2. sz., 148-166. https://doi.org/10.1016/S0885-2006(02)00143-6

Harper, L. V. \& McCluskey, K. S. (2003): Teacher-child and child-child interactions in inclusive preschool settings: Do adults inhibit peer interactions?. Early Childhood Research Quarterly, 18. 2. sz., 163-184.

https://doi.org/10.1016/S0885-2006(03)00025-5

Hayes, A. F. \& Krippendorff, K. (2007): Answering the call for a standard reliability measure for coding data. Communication methods and measures, 1. 1. sz., 77-89.

https://doi.org/10.1080/19312450709336664

Herbainé Szekeres Erika és Szekeres Ágota (2016): Enyhén értelmi fogyatékos gyermekeket integráló „jó” és „rossz” közösségek összehasonlítása. Gyógypedagógiai Szemle, 3. Sz., 149-167.

Keszei Barbara, Böddi Zsófia és Dúll Andrea (2016): Lehetőségek és nehézségek a természetes megfigyelésben: Egy óvodai vizsgálat tapasztalatai. Prosperitas, 3. 2. sz., 63-86.

Keszei Barbara, Böddi Zsófia, Geszten Dalma, Hámornik Balázs Péter és Dúll Andrea (2019): A Krippendorf-Alfa (KALPHA) alkalmazása a gyakorlatban. Alkalmazott Pszichológia, 19. 2. sz., 57-75.

Ketskeméty László, Izsó Lajos és Könyves Tóth Előd (2011): Bevezetés az IBM SPSS Statistics programrendszerbe. Módszertani útmutató és feladatgyüjtemény statisztikai elemzésekhez. Artéria Stúdió Kft., Budapest.

Koster, M., Nakken, H., Pijl, S. J. \& Van Houten, E. (2009): Being part of the peer group: A literature study focusing on the social dimension of inclusion in education. International Journal of Inclusive Education, 13. 2. sz., 117-140.

https://doi.org/10.1080/13603110701284680 
Lányiné Engelmayer Ágnes (2014): Változásban a pszichológiai és gyógypedagógiai diagnosztika. Neveléstudomány, 2. 3. sz., 33-52. https://doi.org/10.1080/13603110701284680

Mérei Ferenc (1989): Társ és csoport. Akadémiai Kiadó, Budapest.

Mérei Ferenc és V. Binét Ágnes (2006): Gyermeklélektan. Medicina Könyvkiadó Rt., Budapest.

McCabe, P. C. \& Marshall, D. J. (2006): Measuring the social competence of preschool children with specific language impairment: Correspondence among informant ratings and behavioral observations. Topics in Early Childhood Special Education, 26. 4. sz., 234-246. https://doi.org/10.1177/02711214060260040401

Odom, S. L. (2000): Preschool inclusion: What we know and where we go from here. Topics in early childhood special education, 20. 1. sz., 20-27. https://doi.org/10.1177/027112140002000104

Odom, S. L. (2002): Narrowing the question: Social integration and characteristics of children with disabilities in inclusion settings. Early Childhood Research Quarterly, 17. 2. sz., 167-170. https://doi.org/10.1016/S0885-2006(02)00150-3

Pepler, D. J. \& Craig, W. M. (1995): A peek behind the fence: Naturalistic observations of aggressive children with remote audiovisual recording. Developmental Psychology, 31. 4. sz., 548.

https://doi.org/10.1037/0012-1649.31.4.548
Sántha Kálmán (2012): Numerikus problémák a kvalitatív megbízhatósági mutatók meghatározásánál. Iskolakultúra, 22. 3. sz., 64-73.

Slunjski, E. \& Ljubetić, M. (2014): Play and its pedagogical potential in a preschool institution. Croatian Journal of Education: Hrvatski časopis za odgoj i obrazovanje, 16. (Sp. Ed. 1), 127-141.

Smith, P. K. (2010): Children and Play. WileyBlackwell, Chichester.

Stanton-Chapman, T. L. (2015): Promoting positive peer interactions in the preschool classroom: The role and the responsibility of the teacher in supporting children's sociodramatic play. Early Childhood Education Journal, 43. 2. sz., 99-107. https://doi.org/10.1007/s10643-014-0635-8

Stanton-Chapman, T. L. \& Snell, M. E. (2011): Promoting turn-taking skills in preschool children with disabilities: The effects of a peer-based social communication intervention. Early Childhood Research Quarterly, 26. 3. sz., 303-319. https://doi.org/10.1016/j.ecresq.2010.11.002

Szokolszky Ágnes (2004): Kutatómunka a pszichológiában. Metodológia, módszerek, gyakorlat. Osiris Kiadó: Budapest.

\section{Social interactions in integrating preschool groups: an observational study}

The focus of the study was to examine social relationships in integrating preschool groups. Social integration is a crucial fact regarding the success of integration. The aim of the study was to reveal the social interactions of children with special educational needs attending integrating preschool groups. Social interactions of six children with special educational needs (non-autistic) (3 girls and 3 boys between the age of 5 and 7, mean age: 6.17 ys) were studied by using the method of natural observation. Videos were recorded several times in 5 integrating groups at morning time. After developing the categories, reliability was tested on the category system. Observation was executed on approximately 5 hrs long videotaped periods of children's behaviour. Results were analysed by counting the frequencies of the categories. The observed children with special educational needs occupied themselves with play in the majority of the observed periods. Activities were carried out in interaction, mostly with peers more than half of the observed cases. By analysing and comparing the results to scientific articles it was concluded that observed children can be seen as members of the groups and were playmates of other members of the preschool groups.

Keywords: integration, preschool, social interaction, natural observation

Böddi Zsófia (2019): Társas interakciók megfigyeléses vizsgálata integráló óvodai csoportokban. Gyermeknevelés, 7. 2-3. sz., 28-44. 